Published by LPMP Imperium

Journal homepage: https:/ / ejournal.imperiuminstitute.org/ index.php/ BERDAYA

\title{
Pelatihan Pengelolaan Keuangan dan Pemasaran Untuk Pengembangan U saha Warung di Kembangan U tara Jakarta Barat
}

\author{
Lusia Sri Arini, Harnovinsah, Swarmilah Hariani* \\ Program Studi A kuntansi, Fakultas Ekonomi dan Bisnis, Universitas Mercu Buana Jakarta
}

\begin{abstract}
Community service has been carried out by analyzing the situation of partners who do not get used to doing financial bookkeeping, how to serve food is still not arranged to attract consumers, the cooking area and guest room are not neat and less clean, also how to offer food to consumers that are still not friendly. For this reason, service partners are provided with food stalls by helping them to devel op their food stalls. The activities carried out are providing knowledge about bookkeeping, financial management with theory and practice, marketing management, and entrepreneurship. Dining and dining room settings kitchen so that it looks clean and organized. The output of this service is so that the shop owner is moreskilled in managing the rice shop business and it is hoped that knowing the above knowledge will be more developed and become the goal of consumers to eat at the rice shop. A fter training partners get financial knowledge, partners can do bookkeeping every day so that they can design their business development. $M$ arketing and entrepreneurship knowledge can support the success of current and future rice food stalls and in the end, the development of rice stalls will improve the partners' lives and economies.
\end{abstract}

Keywords

Finance, marketing, entrepreneurship

BERDAYA : Jurnal Pendidikan dan Pengabdian

Kepada $M$ asyarakat

Vol 2, N 0.3, D esember 2020,

pp.99- 106

elSSN 2721-6381

\section{Article History}

Received 18Jun€ 2020 / Accepted 1Dec 2020 / First Published: 30 Dec 2020

To cite this article

Arini, L., Harnovinsah, H., \& Hariani, S. (2020). Pelatihan Pengelolaan Keuangan dan Pemasaran Untuk Pengembangan Usaha Warung di Kembangan Utara Jakarta Barat. BERDAYA: Jurnal Pendidikan Dan Pengabdian Kepada Masyarakat, 2(3), 99 - 106.

DOI: $10.36407 /$ berdaya.v2i3.187

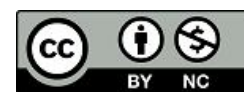

(C) 2020. This open access article is distributed under a Creative Commons Attribution (CC-BY-NC) 4.0license 
ABSTRAK

Pengabdian masyarakat telah dilaksanakan dengan menganalisa situasi mitra tidak membiasakan melakukan pembukuan keuangan, cara menyajikan makanan masih belum ditata agar menarik konsumen, tempat masak dan ruangan tamu belum rapih dan kurang bersih, juga cara menawarkan makanan yang kepada konsumen yang masih kurang ramah. Untuk itu dilaksanakan pengabdian kepada mitra warung makan dengan membantu agar dapat mengembangkan warung makannya.

Kegiatan yang dilakukan untuk memberikan pengetahuan tentang pembukuan, pengelolaan keuangan dengan teori dan praktek, manajemen pemasaran dan kewirausahaan. Pengaturan ruangan makan dan dapur agar nampak bersih dan tertata. Luaran pengabdian ini adalah agar pemilik warung lebih terampil dalam mengelola usaha warung nasi dan diharapkan dengan mengetahui pengetahuan diatas akan lebih berkembang dan menjadi tujuan konsumen untuk makan di warung nasi. Setelah diberikan pelatihan mitra mendapat pengetahuan keuangan maka mitra dapat melakukan pembukuan setiap hari sehingga dengan pembukuan tersebut mereka bisa merancang pengembangan usahanya. Pengatahuan pemasaran dan kewirausahaan bisa menunjang keberhasilan warung makan nasi saat ini dan mendatang dan pada akhirnya pengembangan warung nasi akan meningkatkan taraf hidup dan perekonomian mitra.
Profil Penulis Lusia Sri Arini, Harnovinsah, Swarmilah Hariani

Program Studi Akuntansi, Fakultas Ekonomi dan Bisnis, Universitas Mercu Buana Jakarta

\section{Penulis korespondensi:}

Swarmilah Hariani

email:

swarmilah@mercubuana.ac.id

Kata Kunci : Keuangan, pemasaran, kewirausahaan

Reviewing Editor

Hendryadi, STIE Indonesia Jakarta

\section{PENDAHULUAN}

Usaha warung makan nasi banyak dilakukan oleh ibu rumah tangga untuk membantu kesejahteraan keluarga. Kebanyakan usaha rumah makan tidak dipersiapkan secara manajemen.Sehingga dalam perjalanannya mempunyai hambatan untuk keberlangsungannya usaha warung makan tersebut, perlu menyelesaikan masalah yang dihadapi. Untuk itu masalahyang dihadapi warung makan perlu di cari jalan keluarnya seperti kekurangan modal, pembukuan, mengolah makanan yang bergizi,penataan ruangan dan penyajian makanan. Warung makan yang potensial untuk berkembang namun perlu bantuan keterampilan dalam pengelolaan warung makannya. Dalam rangka pengabdian pada masyarakat kami ingin membantu agarpemilik memiliki pengetahuan kewirausahaan seperti pemasarannya, pembukuannya, pengolahan makanannya, dan penyajiannya.

Warung makan nasi buka padapagi hari mulai pukul 08.00 WIB sampai jam14.00 dan sore jam 16.00 WIB sampai jam 20.30. WIB. Selain karena lebih praktis dan harga yang ditawarkan tidak terlalu mahal, alasan lain yang membuat orang suka makan di rumah makan/ warung-warung makan adalah karena adanya perbedaan suasana, serta kenyamanan yang di dapat dari fasilitas- 
fasilias yang memang sengaja disediakan demi kenyamanan para tamu. Waktu juga menjadi salah satu alasan orang lebih memilih makan di rumah makan, karena belum tentu semua orang sempat untuk menyediakan makanan di rumah. Hal tersebut yang membuat usaha rumah makan dapat dijadikan sebagai peluang usaha yang menjanjikan. Karena peluang bisnis tersebut akan dibutuhkan sampai kapanpun, dan prospek kedepannya semakin bagus seiring bertambahnya jumlah penduduk.

Rata-rata modal yang digunakansetiap hari kurang lebih $\mathrm{Rp} 700.000$ rupiah.Adapun masakan terdiri atas nasi putih, ayam goreng, tempe goreng, tahu goreng, ikangoreng, mie goreng, acar, sayur tumis, sayursup dan sambel lalap. Warung makan nasi $A$ berdiri sudah lebih dari 4 tahun sedangkan warung makan B baru lebih dari 3 tahun. Adapun konsumen adalah masyarakatdisekitar tempat usaha tersebut. Untuk pembukuan setiap hari jarangdilakukan sehingga untuk perencanaaninvestasi belum terpenuhi. Sedangkan masakan yang sehari-hari diproduksi dirasakan belum menjamin memiliki nilai giziyang cukup. Penyajian makanan yang sudah dilakukan seperti mencampur nasi dengan lauk pauk dilakukan tanpa seni, sehingga biasmengurangi nilai makanan tersebut. Peralatanyang dimikili seperti kompor, panci, penggoreng, blender, dan al at dapurlainnya. Namun untuk alat bakar membakarbelum dimiliki sehingga masakan yangdiproduksi masih kurang lengkap sepertipepes, ikan bakar, sate dan lain sebagainya.

Rumah makan itu sendiri memiliki tantangan untuk tetap mempertahankan usahanya antara lain bagaimana menjaga kualitas pelayanan agar dapat bersaing dengan produk serupa dan juga produk pengganti lainnya yang saat ini semakin banyak bermunculan. Salah satu faktor yang harus diperhatikan dalam menjaga kualitas pelayanan yaitu dengan memberikan pelayanan yang memuaskan, sesuai dengan atau melebihi harapan pelanggan. Sehingga dirasakan sangat penting untuk mengetahui pelayanan yang diharapkan oleh pelanggan. A tas dasar hal tersebut di atas maka kami mengadakan kegiatan pengabdian masyarakat.

Sebagaimana telah dinyatakan dalam analisis situasi bahwa permasalahan yang dihadapi adalah terkait dengan pengelolaan keuangan rumah tangga, pencatatan, maka rumusan masalahnya bagaimana para pemilik warung makanan bisa melakukan pencatatan dan penghitungan pengeluaran dengan baik yaitu dengan melakukan pembukuan, sehingga terjadi lebih besar pengeluaran daripada pendapatan, dan bagaimana para pemilik usaha ini dapat memiliki kemampuan untuk mengelola keuangan secara maksimal. Sehingga tujuan konsumenpotensial karena dapat memproduksi makananyang beragam dan lebih berkualitas nilai gizidan variasinya, atau menerima pesanan untukpesta dikembangkan untuk usaha catering. Sehingga akan semakin meningkatkan taraf hidup para pemilik usaha.

\section{Tujuan Kegiatan}

Tujuan utama dari kegiatan pengabdian pada masyarakat ini adalah memberikan pelatihan kepada pemilik usaha mengenai pengelolaan keuangan, sehingga diharapkan tercapai peningkatan pemahaman dan pengetahuan dalam melakukan penghitungan dan pencatatan peneriman dan pengeluaran kas dengan baik sehingga tidak terjadi lebih besar pengeluaran daripada pendapatan. Peningkatan kemampuan dalam mengel ola keuangan. Dan meningkatkan kualitas usaha tersebut baik dalam pelayanan maupun dalam pembukuan. Pemenuhan kebutuhan dan keinginan serta nilai kualitas jasa sangat ditentukan oleh tingkat kepentingan maupun kepuasan pelanggan sebagai pemakainya. Pelayanan yang kurang memuaskan akan 
menyebabkan berkurangnya konsumen atau bahkan hilang karena konsumen berpindah ke jasa layanan lain.

\section{Manfaat Kegiatan}

Manfaat kegiatan pelatihan ini antara lain : para peserta mampu melakukan pencatatan peneriman dan pengeluaran uang dengan baik, mengelola keuangan usahanya, sehingga kondisi keuangan keluarga selalu cukup, baik, dan mempunyai tabungan/ investasi untuk keperluan di masa depan, sehingga terwujud kesejahteraan bagi keluarga. Meningkatkan kualitas pengelolaan keuangan sehingga dapat terwujud keluarga yang sejahtera.

\section{Target dan Luaran Kegiatan}

Dalam mengelolah dan manajemen keuangan usaha yang terpenting adalah memiliki perencanaan yang detail dan rapi. memberikan pengetahuan manajemen keuangan dan pemasaran juga pengetahuankewirausahaan untuk meningkatkan wawasanmitra dalam hal pengelolaan keuangansehingga mampu melakukan pembukuanharian dan bulanan, memberikan pelayanankonsumen yang lebih baik denganpengembangan produk yang disajikan denganteknik penyajian dan pelayanan konsumenyang baik. Membiasakan mencatat keuangan keluarga adalah hal yang sering dilupakan oleh para penjual, berbagai alasan menyebabkan hal tersebut dilakukan diantaranya karena malas dan tidak memiliki waktu.

Memiliki usaha warung dengan system pengelolaan yang sudah jauh lebih baik darisebelumnya, hal ini dapat diwujudkan dengan adanya manajemen pembukuan baik pemasukan dan pengeluaran keuanganwarung setiap aktivitas yang berhubungandengan keuangan setiap hari. Harapan dengan adanya pengelolaan manajemen keuanganyang baik memberikan rasa optimis menyongsong hari depan dengan program pengembangan warung baik berupa investasi modal maupun rencana investasi lainnya yangpada akhirnya dapat bermanfaat dalam halpeningkatan kesejahteraan dan kesehatan. Sejalan dengan itu, diharapkan pula memiliki program dalam pengembangan usaha.

\section{Target Kegiatan}

Target yang dituju dalam kegiatan ini adalah para penjual di wilayah Kembangan Utara, Jakarta Barat. Dimana antara lain sebagai pemilik warung rumah makan, kelontong dan ibu rumah tangga yang memiliki bisnis sendiri dengan latar belakang pendidikan rata-rata sampai sekolah menengah, serta latar belakang ekonomi keluarga menengah ke bawah. Jumlah peserta yang hadir sebanyak 25 orang. Keberhasilan pelaksanaan pengabdianpada masyarakat ini dilihat dari tolok ukur sebagai berikut:

1. Untuk Pelatihan Keuangan peserta sudah mulai membuat dan melaksanakan pembukuan setiap hari (harian).

2. Pelatihan Kewirausahaan mereka sudah mulai memahami pentingnya memiliki jiwa wirausaha misalnya semua aktivitas yang digunakan untuk berjualan dihitung dan dibukukan sehingga tahu selisih antara pembelian bahan dan hasil berjualan.

3. Pelatihan Pemasaran memberikan dampak kepada mitra dalam melayani konsumen lebih ramah dan tepat waktu.

4. Pelatihan manajemen buat pengembangan varasi dan jenis makanan yang disajikan memberikan dampak pada menu makanan yang disajikan lebih beragam atau 
bervariasi, misalnya ikan tidak hanyadigoreng tetapi disajikan dengan bumbu rujak, dan sebaianya.

5. Pengetahuan Gizi memberikan dampakpada warna makanan dan rasa makanan. Terlihat pada sebelum pelatihan sayurandiiris-iris dahulu baru dicuci setelah dilatih sayuran dicuci terlebih dahulu barudiiris-iris sehingga nilai gizinya lebih bagus.

\section{Luaran Kegiatan}

1. Kegiatan pelatihan meningkatkan pemahaman dan keahlian peserta khususnya para pemilik warung rumaha makan dalam menghitung dan mencatat penerimaan dan pengeluaran, dapat memahami pembukuan.

2. Kegiatan pelatihan meningkatkan kemampuan peserta dalam mengelola keuangan dan manajemen keuangan terutama dalam menentukan skala prioritas pengeluaran.

3. Hasil kegiatan ini akan didesiminasikan dan diserahkan pada Jurnal Program Pengabdian M asyarakat.

\section{MATERI DAN METODE}

Untuk mengatasi permasalahan tersebut sebagaimana disebutkan dalam bab 1, maka dapat dilakukan berbagai pemecahan masalah sebagai berikut; (1) nemberi pemahaman mengenai pentingnya pengelolaan/ manajemen keuangan dan pemasaran agar dapat meningkatkan tabungan dan investasi. (2) melakukan praktik mencatat penerimaan dan pengeluaran dan membuat anggaran dalam usaha. Khalayak sasaran yang strategis dalam kegiatan ini adalah pemilik warung makan di Kembangan Utara, Jakarta Barat sejumlah 25 orang.

\section{M etode Kegiatan}

Metode yang digunakan dalam kegiatan ini adalah dalam bentuk pelatihan atau training singkat pengelolaan keuangan rumah tangga dan investasi dengan menggunakan modul pengelolaan keuangan. Peserta yang berasal dari ibu-ibu rumah tangga di Kembangan Utara wilayah Jakarta Barat diberikan pelatihan dengan kegiatan berupa : (1) Metode klasikal pemberian materi dan dilanjutkan dengan sesi tanya jawab; (2) Metode Latihan/ Praktek; pemberian kertas keja yang diisi sesuai dengan kondisi ril peserta

\section{HASIL DAN PEMBAHASAN}

Pelatihan yang dilakukan fokus pada sistem berbasis kompetensi, hal ini disadari bahwa pelatihan yang dilakukan secara tradisi atau konvensional menghasilkan peserta pelatihan yang hanya memiliki pengetahuan apa yang harus dilakukannya. Sementara model yang berbasis kompetensi, peserta setelah selesai mengikuti pelatihan diharapkan tidak saja sekedar tahu tetapi juga dapat melakukan sesuatu yang harus dikerjakan. Dalam sistem berbasis kompetensi, pelatihan untuk Karyawan / UKM difokuskan pada kinerja aktual khususnya kinerja organisasi. Dalam sistem ini tahap awal yang harus dirumuskan adalah fungsi-fungsi apa yang harus dilakukan peserta dengan baik. Dari uraian tersebut maka suatu pelatihan dirancang agar peserta dapat menjalankan fungsinya sesuai standar. Selain agar peserta dapat berfungsi dengan baik, maka mereka dapat belajar di tempat kerja atau dengan sarana lain.

Manajemen keuangan dalam menjalankan sebuah usaha kecil mikro adalah salah satu aspek penting yang menentukan kesuksesan usaha. Dengan manajemen yang baik maka akan diperoleh laba yang jelas jumlahnya, dan akan terjadi pengambilan keputusan yang tepat. Program pelatihan kepada pelaku usaha toko kelontong/ warung ini 
dapat memberikan wawasan dan bekal pada pelaku usaha akan manajemen keuangan. Berikut photo dalam kegiatan program pengabdian masyarakat.

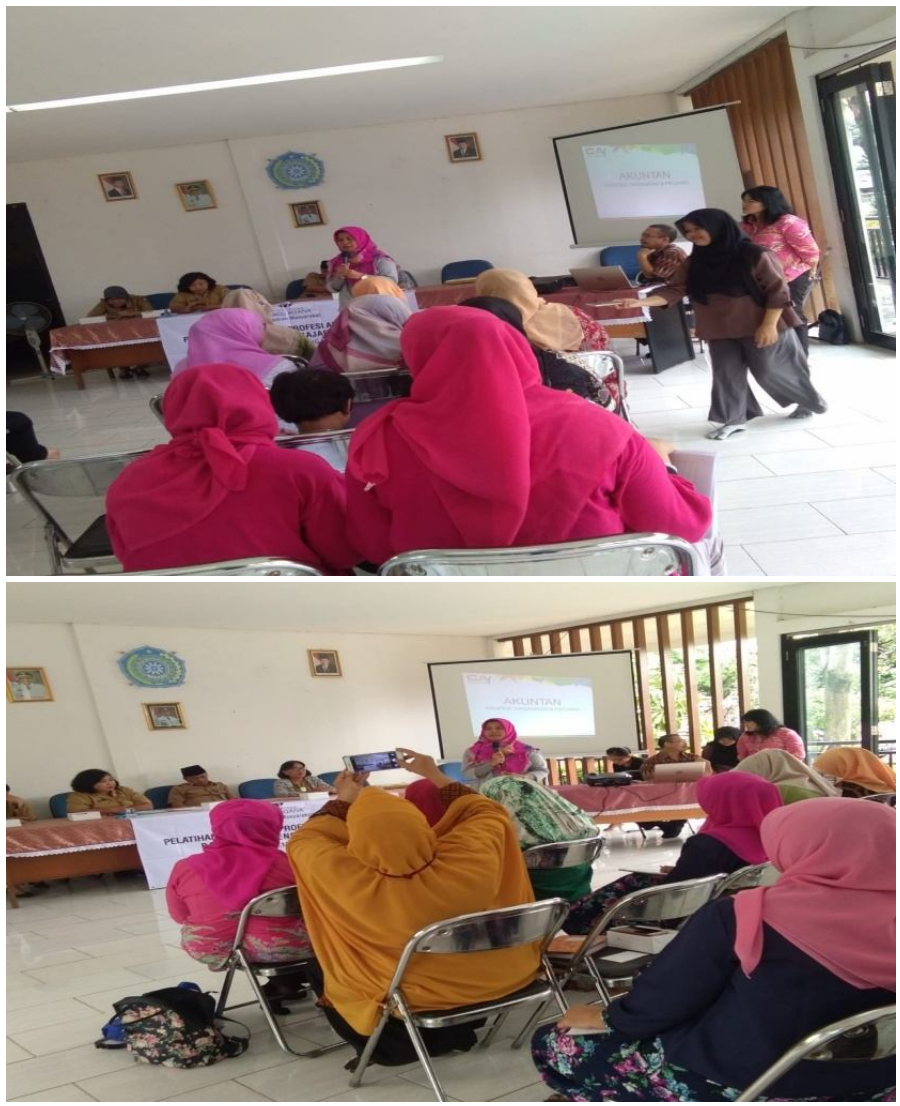

Gambar 1.

Dokumentasi kegiatan Sumber: tim lapangan

\section{Evaluasi Kegiatan}

Metode pelatihan merupakan gabungann antara pelatihan bidang pemasaran dan konsep kewirausahaan. Untuk kegiatan inipelatihan pemasaran diberikan oleh dosen Universitas Mercu Buana. Pemberian pembekalan bidang pemasaran diberikan dengan bahan pemasaran produk secara umum, serta tentang kewirausahaan serta bagaimana agar dapat bekerja dengan SMART. Pada saat pemberian pelatihan tidak hanya cerita tentang teori tetapi lebih terhadap pembahasan masalah yang mereka hadapi selama ini. Untuk bidang kewirausahaan, ruang pelatihan dibagi menjadi untuk para pelaku usaha yang memproduksi barang, jasa, serta berdagang atau berjualan. Mereka dapat membahas masalah-masalah yang mereka hadapi selama ini.

Lalu acara pelatihan dilanjut dengna FGD, tentang masalah-masalah yang dihadapi oleh pelaku UMKM dikaitkan dengan kebutuhan pelatihan untuk menyelesaikan masalah yang ada. Ternyata masalah yang paling banyak memang masalah pada bidang keuangan, baik itu pada pengelolaannya yang masih tercampur akan pengelolaan keuangan keluarga serta keuangan usaha, kurangnya modal, sulitnya mendapatkan jejaring dengan pihak lembaga keuangan atau perbankan. Untuk bidang pemasaran masalah yang mereka hadapi 
adalah masalah dari sulitnya mendapatkan tempat untuk berjualan, sulitnya memperluas pasar, ketidaktahuan untuk melakukan alat promosi dan pentingnya pengembangan produk. Selain dari itu pada bidang operasi adalah sulitnya mendapatkan supplier atau pemasok yang lokasinya dekat dengan tempat mereka berusaha serta sulitnya mendapatkan barang.

Seperti telah dikemukakan bahwa langkah pertama dalam kegiatan pemasaran adalah meneliti kebutuhan dan keinginan konsumen. Berapa jumlahnya, bagaimana daya belinya, di mana tempat konsumennya, dan berapa permintaannya. Semua ini merupakan informasi penting bagi pemasaran produk baru. Keunggulan bersaing perusahaan baru terletak pada perbedaan(diferensiasi) perusahaan tersebut dengan pesaingnya dalam hal:

1) Kualitas yang lebih baik.

2) Harga yang lebih murah dan bisa ditawar.

3) Lokasi yang lebih cocok, lebih dekat, lebih cepat.

4) Seleksi barang dan jasa yang lebih menarik.

5) Pelayanan yang lebih menarik dan lebih memuaskan konsumen.

6) Kecepatan, baik dalam pelayanan maupun dalam penyaluran barang

\section{Kesimpulan}

\section{KESIM PULAN}

Respon peserta terlihat melalui observasipelatihan berdampak kepada kerapihan dalam manajemen keuangan, kerapihandan kebersihan ruangan baik dapurmaupun tempat makan dan tempatpenyajian makanan. Dengan memahami pengetahuan kewirausahaan mereka akan lebih berfikir dalam jangka panjang untuk keberlangsungan usaha warung makan. Memahami ilmu pemasaran mereka lebih menghargai konsumen dan menjadikan konsumen sebagai mitra sehingga diharapkan konsumen kembali lagi untuk belanja di warung makan. Dengan dilatihnya tata boga mereka lebihmenekankan nilai gizi dan ragammakanan yang dibutuhkan konsumen. Semua makanan yang disajikan lebih memiliki nilai gizi yang baik.

\section{Saran kegiatan Lanjutan}

Kegiatan pelatihan ini sebaiknya dilakukan secara berkelanjutan kepada para peserta yang sama sampai mereka paham dan dapat mengimplementasikan .Melihat manfaat dari pelatihan ini yang cukup besar sebaiknya khalayak sasaran diperluas lagi.

\section{REFERENSI}

Hisrich, R. D., Peters, M. P. and Shepherd, D.A. (2010). Entrepreneurship, 8th edn.,New York: McGraw-Hill Irwin

Kuratko, D.F. (2005). The emergence of entrepreneurship education:Development, Trends andChallenges. Entrepren eurship Theoryand Practice

Ronstadt, R. C.(1984). Entrepreneurship Dover, MA:Lord Publishing Co

Vesper. K. H. and Gartner, W.B.(1997). Measuring progress in entrepreneurship Education. Journal ofBusiness Venturing, 12, 403-421. 


\section{FUNDING}

Kegiatan ini merupakan bagian dari program Pengabdian Kepada Masyarakat yang didanai oleh Fakultas Ekonomi dan Bisnis, Universitas Mercu Buana Jakarta.

\section{COMPETIN G INTERESTS}

Penulis menyatakan bahwa tidak ada konflik kepentingan untuk diungkapkan. 